УДК: 159.923.2-056.83:364-786

DOI: $10.26565 / 2410-1249-2019-11-04$

\title{
DYNAMICS OF PSYCHOLOGICAL CHARACTERISTICS OF DRUG ADDICTS IN THE PERIOD OF REHABILITATION FOR UP TO ONE YEAR AND FROM ONE TO FIVE YEARS
}

\author{
Svitlana Mykhailiv* \\ post-graduate student of the Department of Psychology \\ Poltava V.G. Korolenko National Pedagogical University \\ Ostrogradskogo, 2, Poltava, 36003, Ukraine \\ *E-mail: svitlo1504@gmail.com https://orcid.org/0000-0003-1033-0719 \\ Myshko Nadiia** \\ Poltava V.G. Korolenko National Pedagogical University \\ Ostrogradskogo, 2, Poltava, 36003, Ukraine \\ **E-mail: mushko_nadin@ukr.net https://orcid.org/0000-0002-6354-051X
}

\begin{abstract}
Despite the fact that in Ukraine there are constantly a large number of preventive and corrective measures to prevent and eliminate the phenomenon of drug addiction, statistics show that the problem does not diminish its relevance. Now there is a large number of studies that reveal the personal characteristics of a drug addicts. Many scientists are unanimous that in the period of drug addiction there is a distortion in the personal sphere. However, the features of these distortions at various stages of drug addiction are not fully understood. At the same time, the elimination of psychological dependence on narcotic substances by means of rehabilitation effects is possible only if the knowledge on the psychological characteristics of the addict is taken into account at different stages of the rehabilitation process. The main goal of rehabilitation work is not only the rejection of drugs. This is the development of new value orientations, personal growth in the individual and social sense, the development of human anti-drug resistance properties, the development of responsible choice skills, the formation of the internal locus of control, the formation of a positive life scenario and the availability of internal resources for its implementation. The article analyzes the effect of rehabilitation methods on the personality traits of drug addicts with short-term and long-term rehabilitation. The study included 60 people, of which 30 drug addicts were with a period of rehabilitation up to one year and 30 drug addicts with a period of rehabilitation from one year to five years. The complex of diagnostic tools includes methods for studying the level of aggressiveness, anxiety scales, behavior in a conflict situation, assessing the neuropsychic personality tension, a questionnaire for studying the level of impulsivity, a questionnaire for studying the level of subjective control, a questionnaire for studying wellbeing, activity, mood. The dynamics of psychological characteristics of drug addicts in the period of rehabilitation up to one year and from one to five years was determined.
\end{abstract}

KEY WORDS: drug addict, psychological characteristics of drug addicts, rehabilitation.

Problem formulation. Due to date, there is a substantial range of studies that reveal the identity of the drug addict. Continuous preventive-informative methods and a lot of methods of psycho-correction are actively applied across the country in order to prevent and eliminate a phenomenon of drug addiction. At the same time, statistics of detected drug addiction shows that the problem does not decrease its relevance. Many scientists agreed on the fact that during the period of drug addiction there is a distortion in the personal aspect, but the peculiarities of these distortions at different stages of drug addiction are not completely understood. Meanwhile, the elimination of psychological dependence on drug-addictive substances with psycho-correction and rehabilitation influence is possible only with the knowledge of the psychological characteristics of the drug addict at different stages of the rehabilitation process.

Social and economic restructuring of the last 1015 years have changed the value systems of modern society. Unfortunately, not all of them are positive. Each of us faces with displays of socially negative behavior - aggressions, addictions, unlawful acts etc. Despite the fact that the issue of deviant behavior among adolescents is very traditional, today appears range of new issues, one of which is an effective way of prevention and correction of the problem - 
oriented on basic psychological determinants of adolescent tendency to deviations. The purpose of this work is to determine the main factors of deviant behavior of adolescents, its analysis and comprehensive generalization of psycho measures.

Deviant behavior is a social behavior that does not conform to the norms in the society. Deviations in the behavior of children and adolescents are those features and expressions, which not only attract attention but also alarming parents, teachers and society. Deviant behavior is different in content and targeting, can manifest itself in various social deviations: evasion study, theft, vandalism, fights, alcoholism, drug abuse, suicide, etc. These features characterize the behavior not only deviations from the standard of conduct, but also pose potential risks to the subject of behavior, development of his personality, the people around him and society (Belycheva, 1993).

Classify deviant behavior of adolescents as follows:

1. Social deviations of selfish orientation: offenses, behavior relating with the desire to obtain material, money, property benefits.

2. Social deviations aggressive orientation action against the person (offenses, disorderly conduct, assault, murder, rape).

3. Deviations socio-passive type: the desire to avoid an active lifestyle, to evade civic duties unwillingness to solve personal and social problems (evasion of studying, vagrancy, alcoholism, drug addiction, toxic mania, etc.). Notable among these deviations takes the suicidal behavior (Zmanovskaya, 2003).

Typically, deviations in behavior and social development of children and adolescents can be reduced in two groups: the situational forms of deviations in behavior (temporary signs or reactions caused by certain factors and circumstances: the reactions of refusal, protests, withdrawals, aggressions, etc.) and the resistant forms of deviations in behavior (developed by one or another type due to unfavorable conditions of life and work in general) (Belycheva, 1993).

The objective of the paper. The aim of this paper is to analyze the dynamics of personality traits of a drug addict during rehabilitation process.
The main material research. The research was conducted by the author during 2016-2018 on the basis of NGO "History of Life". The study included 60 people, of which 30 drug addicts were with a period of rehabilitation up to one year and 30 drug addicts with a period of rehabilitation from one year to five years. The age range of the sample of respondents within rehabilitation period was 18-67 years, the gender composition of the sample was 43 women and 17 men.

Diagnostic tools included the following techniques: Buss-Durkee Hostility Inventory, Level of Impulsivity Questionnaire by Losenkova, V.A., the "Evaluation of Neuro-Psychic Stress" technique by Nemchin, T.A., the questionnaire "The Level of Subjective Control" by Bazhina, Ye.F., Golinkina, E.A., Etkind, L.M., Questionnaire "Feeling, Activity, Mood" by Doskin, V.A., Lavrentieva, N.A., Kulia, V.B., and Miroshnikov, M.P., the Spielberger's State Anxiety Inventory modified by Hanina, Yu.L., and ThomasKilmann conflict mode questionnaire.

The selected methods meet the requirements of standardization, validity, reliability and relate to the aim of the research and material research. Statistical data processing method: Student's t-criterion is presented in the package of statistical tools IBM SPSS Statistics 20.

The dynamics of psychological characteristic of drug addicts within the period of rehabilitation for up to one year (group 1) and from one to five (group 2) will be analyzed, starting with a comparison of selfassessment of functional status of addicts. The research was conducted by us using the Questionnaire "Feeling, Activity, Mood" by Doskin, V.A., Lavrentieva, N.A., Kulia, V.B., and Miroshnikov, M.P. With its help, we managed to determine the prevailing states and attitudes of drug addicts in the period of rehabilitation for up to one year and from one to five. The results of the study in a summarized form are presented in the chart below (Figure 1).

According to the chart (Figure 1), the significant increase in the functional states rate of drug addicts is observed, the number of low indicators decreases and the number of mean and high indicators increases within all method scales. So, low levels of 
well-being are reduced from $64 \%$ to $7 \%$, while average and high rates increase from $13 \%$ to $37 \%$ and from $23 \%$ to $56 \%$.

These differences were established at the level of statistical significance $p \leq 0,001 \quad(t=3,81)$, and therefore, the long-term stage of rehabilitation leads to a decrease of apathy, fatigue and exhaustion of drug addicts, and increases sense of momentum, strength recovery and health.

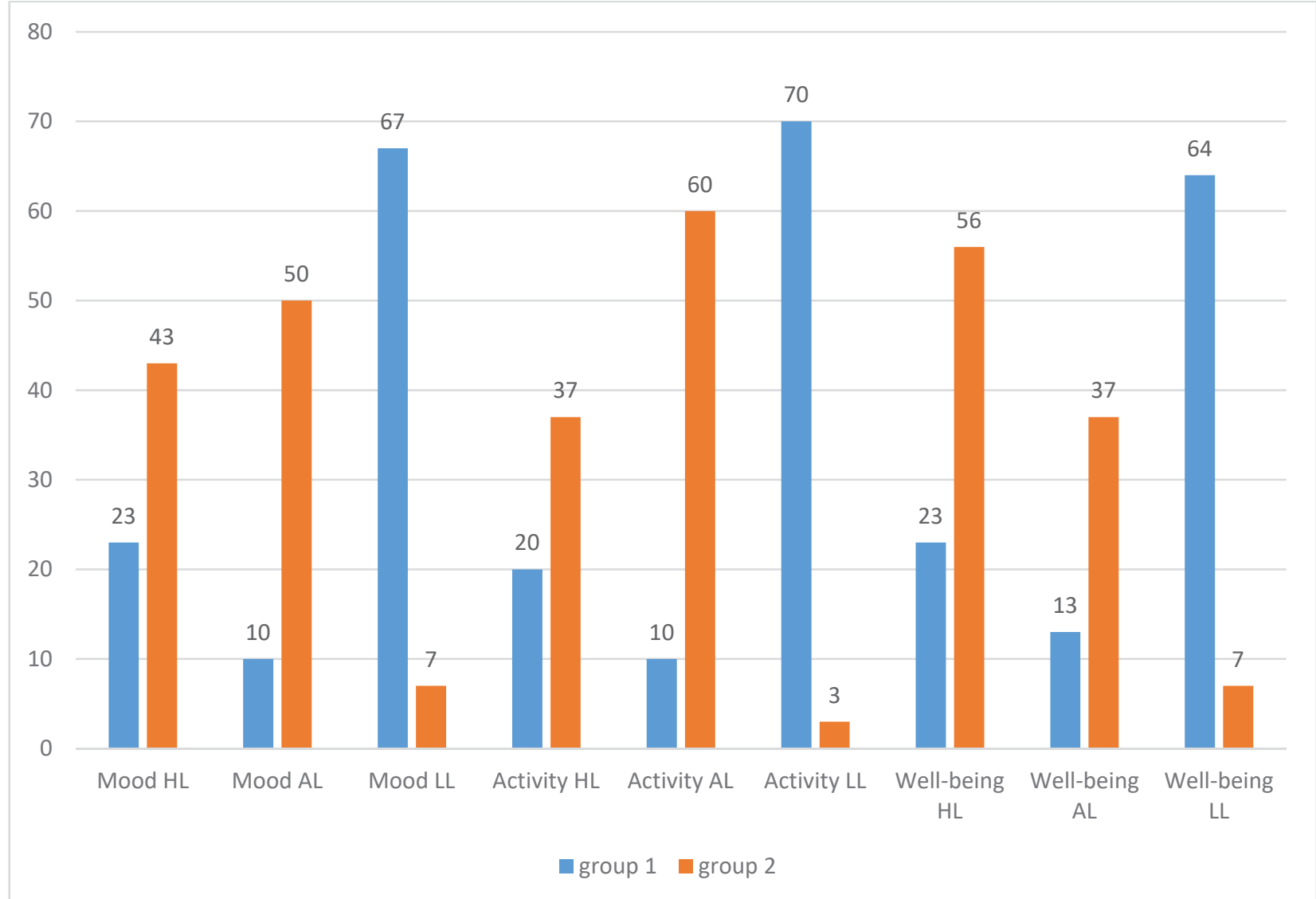

Figure 1. Comparative Chart of Self-assessment rates of functional states of drug addicts in the period of rehabilitation for up to one year and from one to five years $(n=60, \%)$

Low activity rates are reduced from $70 \%$ to $3 \%$, while the average and high rates increase from $10 \%$ to $60 \%$ and from $20 \%$ to $37 \%$. These differences were established at the level of statistical significance $\mathrm{p} \leq 0.001(\mathrm{t}=3.85)$, which indicates an increase in the pace of mental and physical activity, an increase in the concentration and interest of drug addicts within long-term rehabilitation from one to five years.

Low mood rates also decrease from $67 \%$ to $7 \%$, while average and high rates increase from $10 \%$ to $50 \%$ and from $23 \%$ to $43 \%$.

These differences were established at the level of statistical significance $p \leq 0.001(t=3.72)$, and therefore, the five-year stage of rehabilitation of drug addicts leads to an improvement in the emotional state of the subjects that allows them to adequately perceive the events, people, evaluate their opportunities, hope for the future without being concentrated on past failures.

Thus, all components of the functional state of drug addicts in the period of rehabilitation from one to five years have positive dynamics, what is also a favorable ground for other psychological changes. This data is confirmed by the results of the next study of the nervous-psychic stress of drug addicts during the rehabilitation period, which was carried out by using the technique "Evaluation of Neuro-Psychic Stress" by Nemchin, T.A. The received data is shown in Fig. 2.

According to the chart, drug users in the period of rehabilitation from one to five years have a twofold decrease (from $63 \%$ to $30 \%$ ) and a corresponding increase in the average (from $37 \%$ to 
$60 \%$ ) and high (from $0 \%$ to $10 \%$ ) rates of neuropsychological stress. These differences were established at the level of statistical significance $\mathrm{p} \leq 0,01(\mathrm{t}=2,79)$ indicating a general increase in the quality of productivity of mental activity.
Let's consider the results of the study on the impulsivity of drug addicts in the period of rehabilitation for up to one year and from one to five years obtained by using the Losenkova, V.A. method of determining the level of impulsivity (Fig. 3).

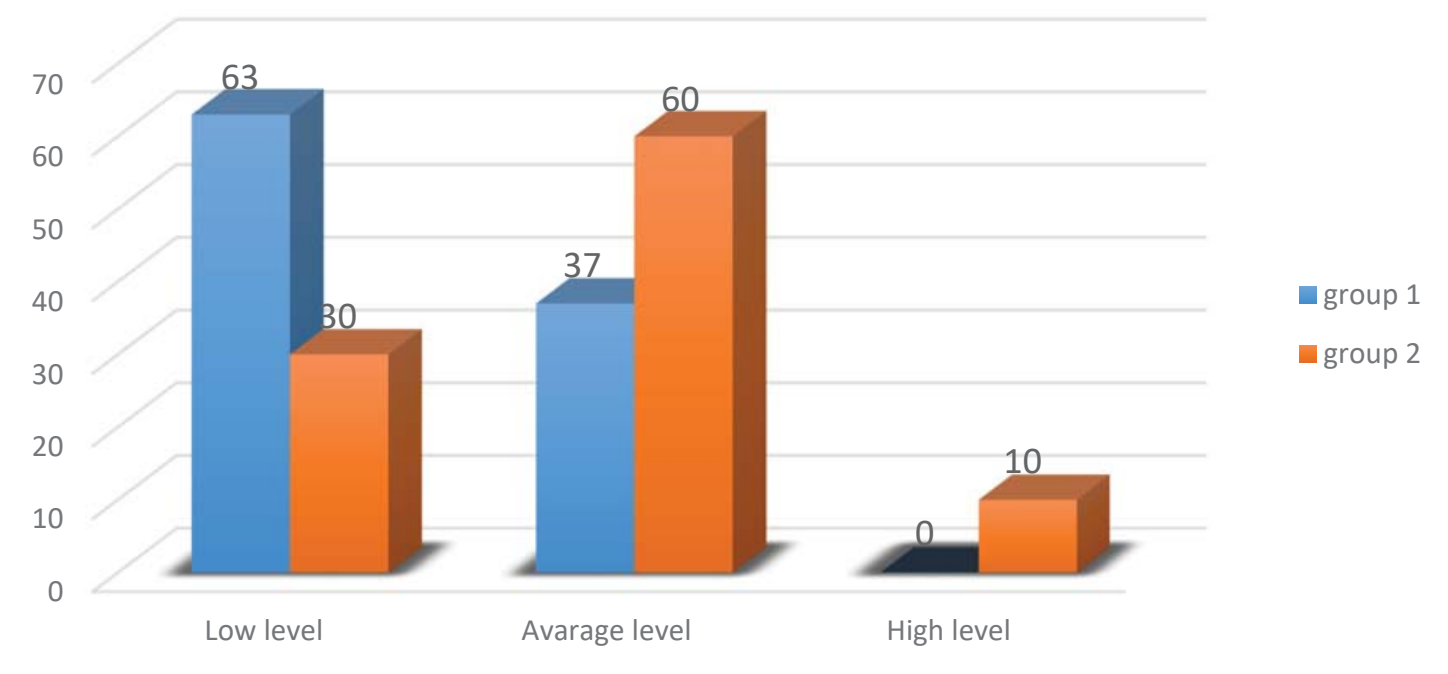

Figure 2. Comparative Chart of nervous-psychic stress rates of drug addicts in the period of rehabilitation for up to one year and from one to five years $(n=60, \%)$

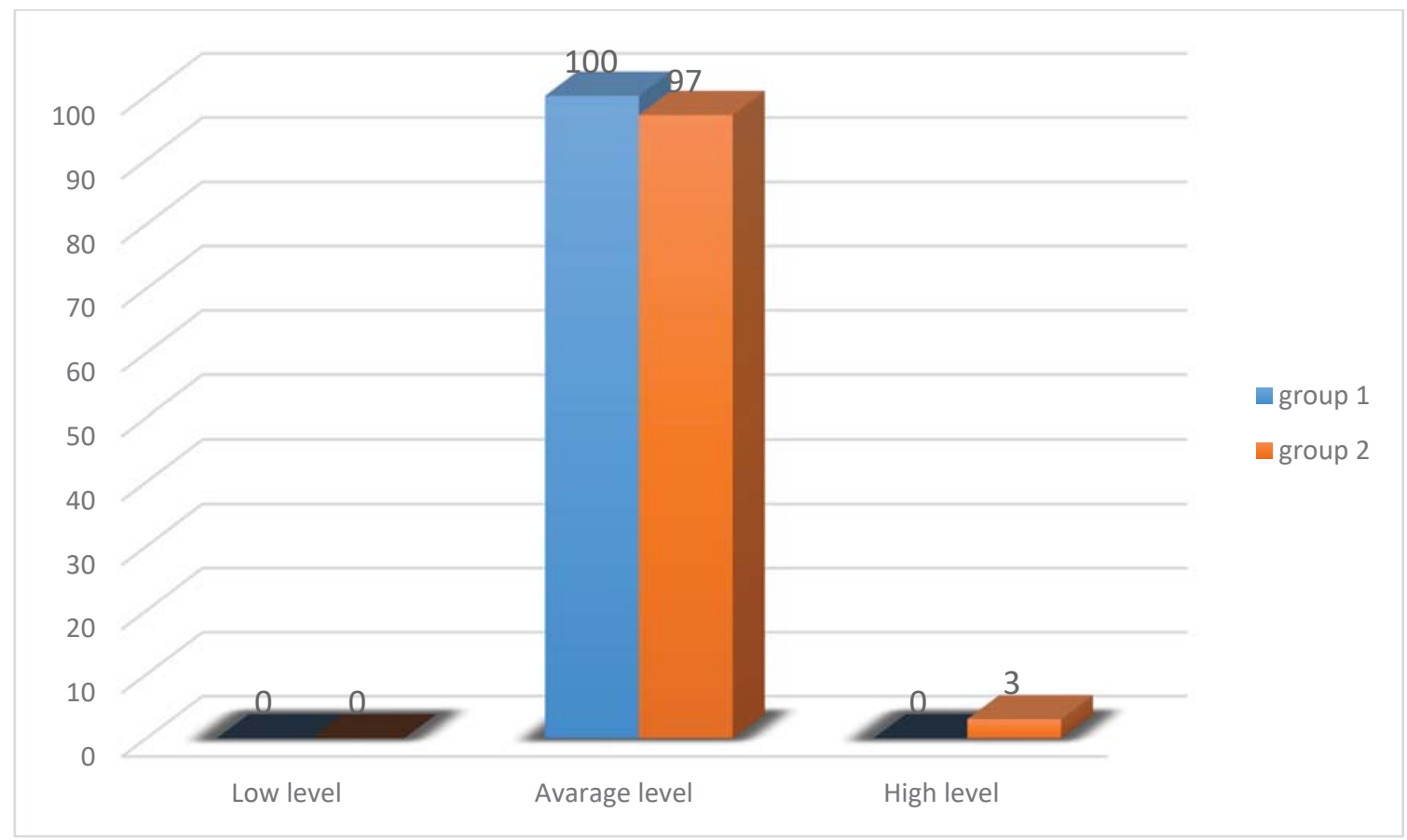

Figure. 3. Comparative Chart of impulsivity rates of drug addicts in the period of rehabilitation for up to one year and from one to five years $(n=60, \%)$

According to the comparative chart (Figure 3), the results of the study of the impulsivity of drug addicts almost did not change, there was a slight increase in rates, so the average impulsivity rates decrease from $100 \%$ to $97 \%$, while the high rates increase from $0 \%$ to $3 \%$. There were no statistically significant differences determined. Consequently, the long-term rehabilitation maintains a certain level of equilibrium in the activity and actions of the subjects involved in the study, the balance in life plans determination and perseverance of efforts to achieve them. 
Let's consider the results of the study on the anxiety rates of drug addicts in the period of rehabilitation for up to one year and from one to five years obtained by using the Spielberger's State Anxiety Inventory (see Figure 4).

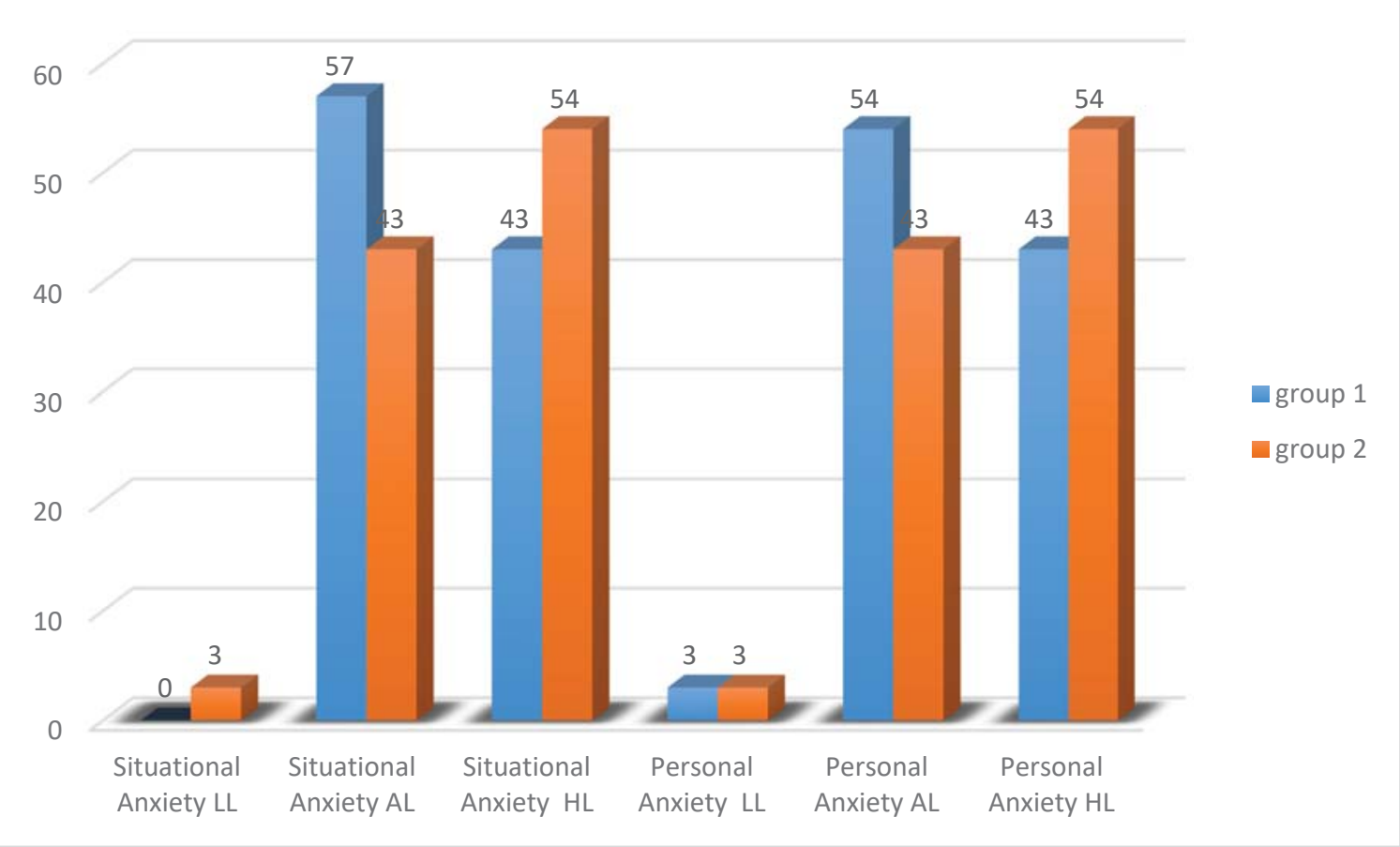

Figure 4. Comparative Chart of anxiety rates of drug addicts in the period of rehabilitation for up to one year and from one to five years $(n=60, \%)$

The comparative chart (Figure 4) shows that rates of situational and personal anxiety of drug addicts in the period of rehabilitation for up to one year and from one to five years are distributed almost equally. Average rates of situational anxiety decreased from $57 \%$ to $43 \%$, and high rates rose from $43 \%$ to $54 \%$. Similarly, average personal anxiety rates decreased from $54 \%$ to $43 \%$, and high rates rose from $43 \%$ to $54 \%$. There were no statistically significant differences determined.

The presence of anxiety as a personality trait is very important, because it determines the behavior of the subject to a large extant, its sufficient level is a natural and mandatory characteristic of the active personality. Every person has his optimal or desirable level of anxiety - so-called useful anxiety. During the period of long-term rehabilitation, drug addicts are aware of a large range of problems and difficulties that were not obvious to them during the active drug use. Therefore, it would be logical to have a higher level of both, situational and personal anxiety in the period of awareness of their problems and acceptance of responsibility for their lives in the present, past and future.
Next let's consider the results of the study on the aggression rates of drug addicts in the rehabilitation period for up to one year and from one to five years obtained by using the Buss-Durkee Hostility Inventory (Figure 5).

The chart shows that aggression rates of drug addicts during the rehabilitation period for up to one year and from one to five years did not change significantly. The rates of Negativism and Resentment grew, while the rate of Guilt fell. Differences in Negativism rates have statistical significance at the level of $p \leq 0.001(t=3.12)$, while Resentment rates have statistical significance at the level of $p \leq 0.001 \quad(t=3.01)$. The results can be explained by specific aspects of rehabilitation work including talking about displaced emotions, attraction and resentment, that reduce feelings of guilt and expands life concepts of personality. In general, drug addicts in the period of rehabilitation for up to one year and from one to five years are characterized by distrust, jealousy and hostility towards the outside world demonstrated ranging from passive discontent to an active verbal and physical confrontation. 


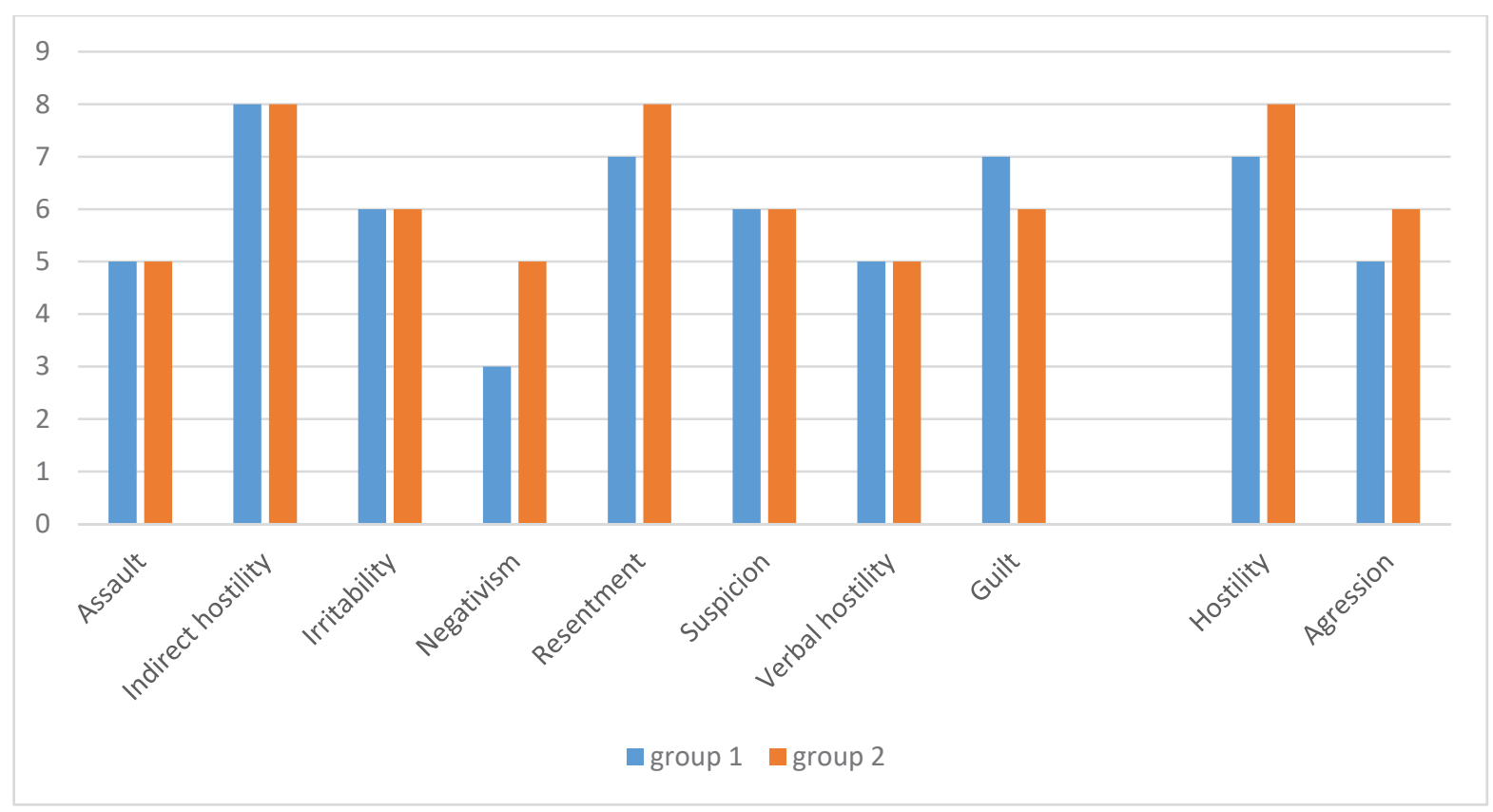

Figure 5. Comparative Chart of aggression rates of drug addicts in the period of rehabilitation for up to one year and from one to five years $(n=60, \%)$

The determination of the Hostility and Aggression of drug addicts in the period of rehabilitation for up to one year and from one to five years showed an increase in both indicators - a high level of Hostility and above average level of Aggression. Differences in the Hostility rates have statistical significance at the level of $\mathrm{p} \leq 0,01 \quad(\mathrm{t}=$ $2,65)$. Consequently, we can state that they have an affective complex including anger, insult and suspicion. Insomnia is defined as the basis for aggression and increases the probability of impulsive acts of aggression aimed at the surrounding world or itself (autoaggression) by destroying Self with psychoactive substances. Particularly, such a tendency in drug addicts does not disappear, it is only realized and taken under its own control by means of rehabilitation and psycho-correction.

Every individual should have a certain degree of aggression, its absence leads to passivity, conformance, etc. Thus, the process of rehabilitation of drug addicts should include the normative aggression of patients, who should become active subjects of their life, break old patterns and build up qualitatively new ones.

Let's consider the results of the research on the conflict response styles of drug addicts in the rehabilitation period for up to one year and from one to five years obtained by using the Thomas-Kilmann conflict mode questionnaire (Kenneth W. Thomas and Ralph H. Kilmann, 1974) modified by Grishina (Figure 6).

The data shows a decrease in the indicators of the conflict response styles, such as Collaborating from $17 \%$ to $3 \%$ and Avoiding from $40 \%$ to $20 \%$. Differences in the Collaborating indicators have statistical significance at the level of $\mathrm{p} \leq 0,01$ $(t=-2,99)$. The rates of Competing increased from $20 \%$ to $27 \%$, as well as the rates of Compromising from $17 \%$ to $27 \%$ and the Accommodating rates from $6 \%$ to $23 \%$. In numerical terms, the most significant is the decrease of Avoiding conflict response style indicators, that had a leading position at the beginning of rehabilitation work. Contrary to this, there is a significant increase in the Accommodating rates that is one of the top three dominant conflict response styles, along with the Competing and Compromising.

The aim of the rehabilitation process is to recover the physical and mental states of an individual to the point where he will be able to rebuild the relationship with society through upgrading a life style. The new identity is based on the positive basic values of the addict, what helps gradually enter into the society and re-socialize. Methods of development are aimed at mobilizing resources and the development of personality by individual's compensatory mechanisms. 


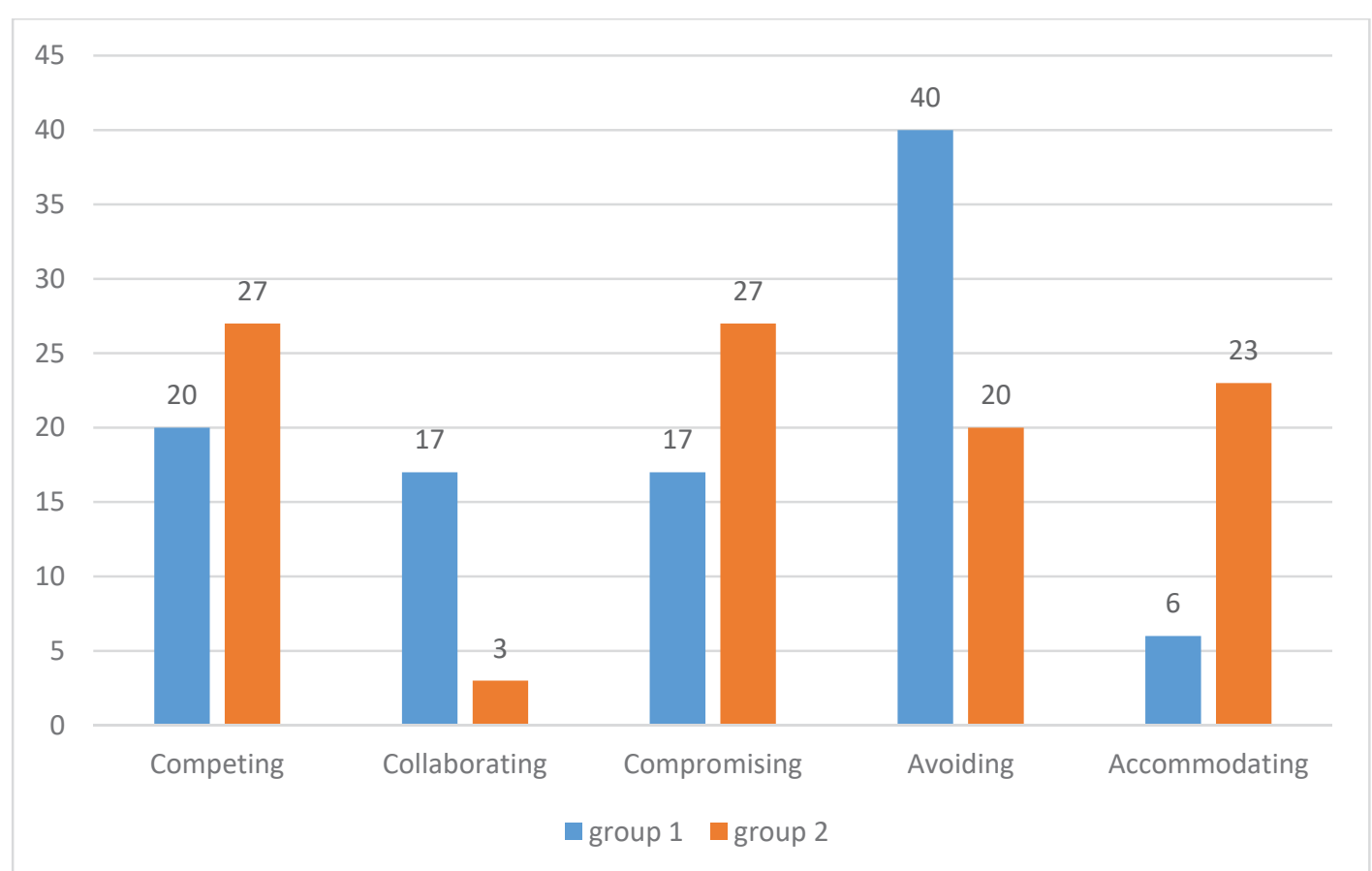

Figure 6. Comparative Chart of the conflict response styles rates of drug addicts in the period of rehabilitation for up to one year and from one to five years $(n=60, \%)$

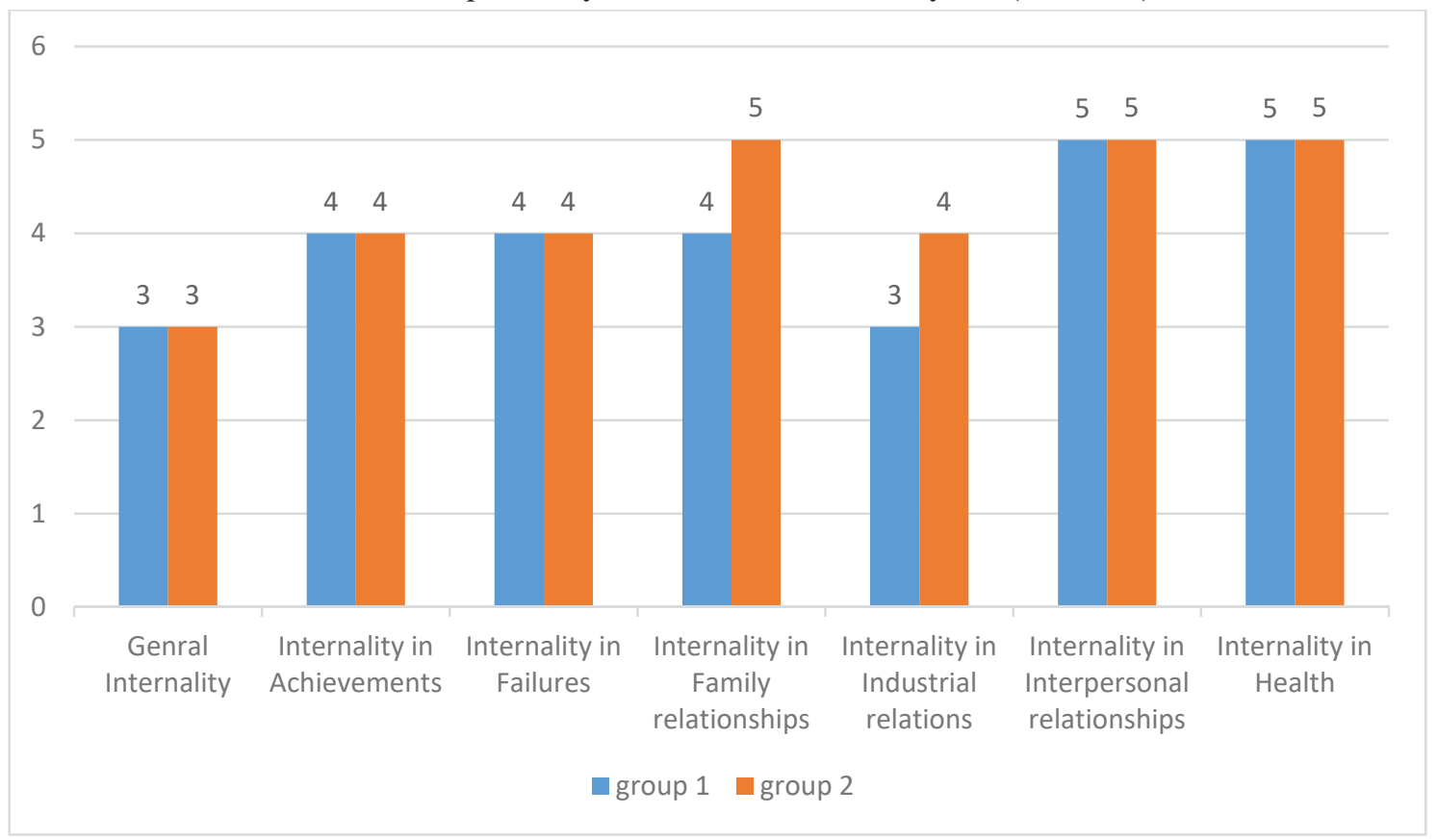

Figure 7. Comparative Chart of the Internality rates of drug addicts of drug addicts in the period of rehabilitation for up to one year and from one to five years $(n=60, \%)$

Interaction within the framework of accordance to the significance and objectives of each rehabilitation is characterized by non-direct, partnerstyle communication, an appeal to dialogue, understanding, rational-critical analysis, best use of the effects of group and interpersonal interaction. The patient is considered as an active subject with positive changes, what definitely determines the positive changes in the ability to manage conflict situations with a wide range of response styles, in situation with various positions of opponents during a communication.

Let's also consider the results of the study of the Internality rates of drug addicts in the period of rehabilitation for up to one year and from one to five years obtained by using the questionnaire "The Level of Subjective Control" by Bazhina, Ye.F., Golinkina, E.A., Etkind, L.M. (see Fig. 7). 
As we can see, drug addicts in the period of rehabilitation for up to one year and from one to five years show an increase in the Internality in Family relationships and Industrial relations. Differences in the indicators of Internality in Family relationships have statistical significance at the level of $p \leq 0,01$ ( $t$ $=2,44)$. This is due to the specific aspects of rehabilitation programs based on universal and family values. The low productivity of an adult leads to the emergence of a psychological crisis and the intention of escaping from reality, also through psychoactive substances. Establishing balance in the family and industrial areas of life becomes a solid foundation for recovery from a life crisis, increasing the feeling of empowerment and the ability to influence and change this world in accordance with own goals and values.

The highest indicators of internality in the period of long-term rehabilitation of drug addicts are the Internality in Family relationships, the Internality in Interpersonal relationships, and Internality in health. These indicators have the boundaries of internality, and therefore, the researchers tend to believe that these aspects of life are influenced by external factors (God, heredity, life circumstances, etc.), and internal (own desires and efforts) factors.

The rest Internality indicators (General Internality, Internality in Achievements, Internality in Failures, and Internality in Industrial relations) are lower, indicating that they are more externalized, and therefore subjects feel less ability to influence their own efforts to achieve the desired results, giving the leading role to a matter of chance, luck-failure, to help of other people, the will of the higher power, etc.

Conclusions. The aim of rehabilitation work is not only a drug refusal, but also the elimination of anti-social behavior, the development of useful skills and abilities, the development of new values sets, in other words a complete change in lifestyle.

The main aim of rehabilitation is to increase personal growth in individual and social aspects, and the main tool for its achievement is the patient's acquisition of integrity. In addition, it involves the development of the properties of anti-drug sustainability of the individual, such as personal identification completion, the formation of skills of responsible choice, the formation of internal locus control, the existence of a positive life scenario, the availability of internal resources for the positive life scenario implementation, elimination of drug use from all possible life aspects of the individual. The deep level of psychotherapy anticipates a direct or indirect reference to the categories of values and sense of social meaning. Therefore, this process is complex and quite conflicting for drug addicts.

\section{REFERENCES}

Belycheva S.A. (1993) Основы превентивной психологии [Fundamentals preventyvnoy psychology. Education]. (in Russian)

Butakov, I.N. (2016) Ценностные ориентации наркозависимых лиц на разных стадиях заболевания [Value orientations of drug addicts at different stages of the disease] Bulletin of the Council of Young Scientists and Specialists of the Chelyabinsk Region. №2 (13) T.3, 30-32. (in Russian)

Zmanovskaya E.V. (2003) Девиантология: Учебник для студентов высших учебных заведений [Deviantology: Textbook for students of higher educational institutions] M.: Academy. (in Russian)

Katkov A.L., Titova V.V. (2002) Интегративно-развивающая, двухуровневая психотерапия наркозависимых. [Integrative developmental, two-level psychotherapy of drug addicts] Narcology. 9, 27-35. (in Russian)

Lichko A.E., Bitenskiy V.S. (1991) Подростковая наркомания [Teenage addiction] L., The medicine. (in Russian)

Mendelevich V.D. (2008) Клиническая и медицинская психология [Clinical and medical psychology] - M.: MEDpress-inform. (in Russian)

Sedikh K.V., Morgun V.F. (2015) Делінквентний підліток. Навчальний посібник із психопрофілактики, діагностики та корекції протиправної поведінки підлітків для студентів психологічних, педагогічних, соціальних, юридичних спеціальностей та інтернівпсихіатрів [Delinquent teenager. A manual on psychoprophylaxis, diagnosis and correction of juvenile delinquency for students of psychological, pedagogical, social, legal and internist psychiatrists] K.: Publishing House "Word". (in Ukrainian)

Frankl V. (2011) Страдания от бессмысленности жизни. Актуальная психотерапия [Suffering from the meaninglessness of life. Actual psychotherapy] Novosibirsk. (in Russian)

Heckhausen H. (2003) Motivation and activity. SPb: Peter. (in Russian)

Mushko N. (2014) The determinants of adolescent deviant behavior. Intellectual Archive. Volume 3, Number 2. Toronto, 105-110. 


\section{ДИНАМІКА ПСИХОЛОГІЧНИХ ОСОБЛИВОСТЕЙ НАРКОЗАЛЕЖНИХ У ПЕРІОД РЕАБІЛІТАЦІї ДО РОКУ ТА ВІД РОКУ ДО П'ЯТИ}

Михайлів С.В., Мишко Н.М.

Полтавський начіональний педагогічний університет імені В.Г. Короленка

Остроградського, 2, Полтава, 36003, Украӥна

Попри те, що в Україні постійно проводиться велика кількість профілактичних та корекційних заходів з метою попередження та усунення явища наркозалежності, статистика свідчить, що проблема не зменшує своєї актуальності. Наразі існує досить велика кількість досліджень, що розкривають особистість наркозалежного. Багато вчених одностайні в тому, що в період наркозалежності відбувається спотворення в особистісній сфері, однак особливості цих спотворень на різних стадіях наркозалежності до кінця не вивчені. Разом із тим, усунення психологічної залежності від наркотичних речовин засобами реабілітаційного впливу можливе лише за умови врахування знання щодо психологічних особливостей наркозалежного на різних етапах реабілітаційного процесу. Головною метою реабілітаційної роботи є не тільки відмова від наркотиків. Це розвиток нових ціннісних орієнтацій, зростання особистості в індивідуальному і соціальному плані, розвиток властивостей антинаркотичної стійкості особистості, сформованість навичок відповідального вибору, сформованість внутрішнього локусу контролю, наявність позитивного життєвого сценарію та наявність внутрішніх ресурсів для його реалізації. У статті проаналізовано вплив реабілітаційних заходів на особистісні особливості наркозалежних, які знаходяться на короткотривалому та довготривалому етапі реабілітації. Дослідженням було охоплено 60 осіб, з яких 30 наркозалежних 3 періодом реабілітації до року та 30 наркозалежних 3 періодом реабілітації з року до 5 років. В комплекс діагностичного інструментарію увійшли методики на дослідження рівня агресивності, шкали тривоги, поведінки в конфліктній ситуації, оцінки нервово-психічної напруги особистості, опитувальник для дослідження рівня імпульсивності, опитувальник для дослідження рівня суб'єктивного контролю, опитувальник для дослідження самопочуття, активності, настрою. Визначено динаміку психологічних особливостей наркозалежних у період реабілітації до року та від року до п'яти.

КЛЮЧОВІ СЛОВА: наркозалежна особа, психологічні особливості наркозалежних, реабілітація.

\section{ДИНАМИКА ПСИХОЛОГИЧЕСКИХ ОСОБЕННОСТЕЙ НАРКОЗАВИСИМЫХ В ПЕРИОД РЕАБИЛИТАЦИИ ДО ГОДА И ОТ ГОДА ДО ПЯТИ \\ Мыхайлив С.В., Мышко Н.М. \\ Полтавский национальный педагогический университет имени В.Г. Короленко \\ Остроградского, 2, Полтава, 36003, Украина}

Несмотря на то, что в Украине постоянно проводится большое количество профилактических и коррекционных мероприятий с целью предупреждения и устранения явления наркозависимости, статистика свидетельствует, что проблема не уменьшает своей актуальности. Сейчас существует достаточно большое количество исследований, раскрывающих личность наркозависимого. Многие ученые единодушны в том, что в период наркозависимости происходит искажение в личностной сфере, однако особенности этих искажений на различных стадиях наркозависимости до конца не изучены. Вместе с тем, устранения психологической зависимости от наркотических веществ средствами реабилитационного воздействия возможно лишь при условии учета знания о психологических особенностях наркозависимого на разных этапах реабилитационного процесса. Главной целью реабилитационной работы является не только отказ от наркотиков. Это развитие новых ценностных ориентаций, рост личности в индивидуальном и социальном плане, развитие свойств антинаркотической устойчивости личности, сформированность навыков ответственного выбора, сформированность внутреннего локуса контроля, наличие положительного жизненного сценария и наличие внутренних ресурсов для его реализации. В статье проанализировано влияние реабилитационных мероприятий на личностные особенности наркозависимых, находящихся на кратковременном и длительном этапе реабилитации. Исследованием было охвачено 60 человек, из которых 30 наркозависимых с периодом реабилитации до года и 30 наркозависимых с периодом реабилитации с года до 5 лет. В комплекс диагностического инструментария вошли методики для исследования уровня агрессивности, шкалы тревоги, поведения в конфликтной ситуации, оценки нервно-психического напряжения личности, опросник для исследования уровня импульсивности, опросник для исследования уровня субъективного контроля, опросник для исследования самочувствия, активности, настроения. Определена динамика психологических особенностей наркозависимых в период реабилитации до года и от года до пяти. КЛЮЧЕВЫЕ СЛОВА: наркозависимый человек, психологические особенности наркозависимых, реабилитация. 